\title{
Survey of heavy metals in the catfish Synodontis clarias
}

\author{
${ }^{1 *}$ I. E. Agbozu, ${ }^{2}$ I. K. E. Ekweozor, ${ }^{3}$ K. Opuene \\ ${ }^{1}$ Department of Pure and Applied Chemistry, Niger Delta University, Wilberforce Island, Yenagoa, Nigeria \\ ${ }^{2}$ Department of Applied and Environmental Biology, Rivers University of Science and Technology, Port Harcourt, Nigeria \\ ${ }^{3}$ Department of Pure and Industrial Chemistry, Faculty of Physical Sciences, University of Nigeria, Nsukka, Nigeria \\ Received 5 June 2006; revised 13 August 2006; accepted 3 September 2006; available online 1 January 2007
}

\begin{abstract}
Elevated levels of heavy metals in the catfish Synodontis clarias can be a good indication of pollution of an aquatic ecosystem due to anthropogenic influence. The concentrations of $\mathrm{Zn}, \mathrm{Cd}, \mathrm{Pb}, \mathrm{Mn}$ and Ni were determined in Synodontis clarias caught along a section of Taylor Creek and its associated tributaries. Samples were collected bimonthly between July 1999 and June 2000 in five stations. The metals: Zn, Cd, Ni, Pb and Mn were recorded in appreciable quantities, signifying their bioavailability. The levels of $\mathrm{Zn}, \mathrm{Cd}, \mathrm{Ni}, \mathrm{Pb}$ and $\mathrm{Mn}$ may have obvious health implications on the rural communities that depend on fish species as fish supplement in view of its rich protein content and its bio-economic value. Generally, the sources of the metals in the catfish appear to be point and diffuse which include rural and agricultural runoff sources in the catchments area. However, the presence of an oil industry activity (Etelebou oil field and flow station) in one of its tributaries appears to be the major point source of the metal pollutants.
\end{abstract}

Key words: Heavy metals, Taylor Creek, catfish, aquatic environment

\section{INTRODUCTION}

The accumulation of heavy metals in an aquatic environment has direct consequences to man and to the ecosystem. Although metals such as $\mathrm{Cu}$ and $\mathrm{Zn}$ are generally regarded as essential trace metals in view of their valuable role for metabolic activities in organisms, other metals like $\mathrm{Cd}, \mathrm{Pb}, \mathrm{Ni}$ and $\mathrm{Hg}$ exhibit extreme toxicity even at trace levels (Merian, 1991; DWAF, 1996). However, it is of interest to note that most essential metals are toxic when supplied in concentrations in excess of the optimum levels. Tam and Wong (1995) stated that heavy metal contamination in aquatic environments is of critical concern due to the toxicity of metals and their accumulation in aquatic habitats. Among the aquatic fauna, fish is the most susceptible to heavy metal toxicants (Nwaedozie, 1998) and so, are more vulnerable to metal contamination than any other aquatic fauna. According to the author, over 54 elements are known to have toxic effect on fish. Heavy metals could enter the aquatic environment from both natural and anthropogenic sources. Natural sources include weathering of minerals and soils

\footnotetext{
*Corresponding author, Email: iwekumo@yahoo.co.uk

Tel.: +234 8038 916768; Fax: +234 8038916768
}

(Merian, 1891). Anthropogenic inputs are mainly from industrial effluents, domestic effluents, rural and urban storm water runoff and spoil heaps (Agbozu and Ekweozor, 2001). The question of heavy metals in freshwater fish first became an issue only in the sixties when serious mercury contamination was detected in Sweden and later in Canada (Ackefors, et al., 1970). Ibok, et al. (1889) reported elevated levels of Hg, Zn, $\mathrm{Cu}, \mathrm{Co}, \mathrm{Sb}, \mathrm{Cd}$, and $\mathrm{Pb}$ in fishes from some streams in Ikot Ekpene area of Nigeria. Fishes were considered as better specimens for use in the investigation of pollutant loads than the water samples because of the significant levels of metals they bioaccumulate. Significant heavy metal levels were recorded in fishes of Warri River (Atuma and Egborge, 1986; Ezemonye and Egborge, 1992); fish and shellfish of the Niger Delta (Kakulu, et al, 1987). Data provided by Agada (1994) also show evidence of selected heavy metal contamination of Chrysicthys nigrodigitatus (catfish) and Pseudotolithus elongatus (Croaker) respectively. Writing on the impact of economic activities on the environment of the Niger Delta, Agbozu (1999) stated that water bodies have been heavily polluted due to the recurring incidence of oil spillage. Most micro- 
populations and invertebrates are eliminated following large-scale spillages, while sublethal levels of oil following several scale spillages have generally affected aquatic resources. The study area has a number of oil wells and one of the major flow stations (Etelebou) within the Niger Delta of Nigeria. The aquatic ecosystem in the area is constituted of a non-tidal freshwater swampy forest, characteristic of those found within the freshwater survey zone of the Niger Delta. The main uses of water in the catchments include domestic, recreational (e.g. swimming) and fishing. Fishing is the major/traditional occupation of the inhabitants in the area. The metal levels under investigation were reported in the surface waters of the study area (Agbozu and Ekweozor, 2001). This study therefore investigates the levels of $\mathrm{Zn}, \mathrm{Cd}, \mathrm{Ni}$, $\mathrm{Pb}$ and $\mathrm{Mn}$ in the catfish Synodontis clarias, an important fish supplement, which has bio-economic value to the inhabitants of the area.

\section{MATERIALS AND METHODS}

\section{Sampling sites}

The locations of the five sampling sites along the Taylor Creek and its tributaries are shown in Fig. 1. The sampling sites were chosen to reflect different activities in the catchments: upstream, midstream and downstream with the flow station environment as reference point. Station 1 was located at the Etelebou flow station environment, on a tributary of Taylor Creek and is surrounded by ponds and lakes, which provides the major fishing grounds in the area during the dry season. Station 2 was located at Ute-pou, a fishing lake, which is downstream of the Etelebou flow station. Station 3 was located at the Bridge linking Nedugo with Ogboloma communities, which is within the area where the tributary empties to Taylor Creek. For the purpose of this study, it is also referred to as midstream. The area is equally dominated by fishing activities. Station 4 was located at the Ogboloma axis along Taylor Creek, which is downstream of the flow station and serves as the only source of drinking water to the community.
Both domestic and agricultural wastes are dumped into this section of the Creek. Nedugo/Agbia axis of Taylor Creek, an upstream station was station 5 . The water body serves as the only source of drinking water besides fishing, washing and swimming. At stations 4 and 5, domestic and agricultural wastes are also dumped into this section of the Creek. Catfish (Synodontis clarias) samples were collected with pond nets and local fishing baskets. Nets were thrown/spread overnight to catch reasonable quantities for experimental studies. Samples were transferred into transparent plastic basins and transported to the laboratory. Samples were collected bi-monthly between July 1999 and June 2000.

\section{Heavy metal analysis}

Whole samples were oven dried and pulverized into fine textures. Two grams of oven-dried samples were dissolved in distilled water in a digestion flask and digested with a mixture of $10 \mathrm{~mL}$ of concentrated nitric acid and $2 \mathrm{~mL}$ of concentrated perchloric acid. The contents of the flask were digested gently and slowly, by heating in a water bath till the contents got to near dryness. It was then set aside to cool. The digest was filtered into a $50 \mathrm{~mL}$ volumetric flask, made up to mark with distilled water. Aliquots of the filtrates were used to estimate the concentration of the various metals by Atomic Absorption Spectrophotometry using Buck Scientific model 200 A (Window and Cutshall, 1976). The digestion and analytical procedures were checked by analysis of DOLT-3 Matrix Certified Reference Material with known concentration for heavy metals (Cantillo and Calder, 1990).

\section{RESULTS}

The results of measured values obtained for the standard reference material (DOLT-3) for the representative metals, which validated the experimental procedures used for the chemical analysis are shown in Table 1. The results of the heavy metal analysis in the catfish Synondontis clarias are shown in Table 2 and illustrated in Fig. 2.

Table 1: Measurement accuracy of standard material (DOLT-3)

\begin{tabular}{llllll}
\hline Value type & $\mathrm{Cd}$ & $\mathrm{Fe}$ & $\mathrm{Pb}$ & $\mathrm{Ni}$ & \\
\hline Certified Value & 19.4 & 1484 & 0.319 & 2.72 & 86.60 \\
Measured Value & $17.6(1.23)$ & $1231.72(37)$ & $0.313(0.03)$ & $2.31(0.08)$ & $79.67(3.2)$ \\
Recovery & $90 \%$ & $83 \%$ & $98 \%$ & $85 \%$ & $92 \%$ \\
\hline
\end{tabular}


Int. J. Environ. Sci. Tech., 4 (1): 93-97, 2007

Table 2: Ranges and mean of heavy metal concentrations $(\mu \mathrm{g} / \mathrm{g})$ in Synodontis clarias

\begin{tabular}{|c|c|c|c|c|c|}
\hline \multirow{2}{*}{ Metals } & \multicolumn{5}{|c|}{ Sample stations } \\
\hline & 1 & 2 & 3 & 4 & 5 \\
\hline Zn Ranges & $(2.20-4.40)$ & $(1.81-3.86)$ & $(2.08-3.96)$ & $(1.91-4.12)$ & (1.85-3.69) \\
\hline Mean \pm S.D & $3.59 \pm 1.09$ & $2.79 \pm 0.80$ & $2.83 \pm 0.84$ & $2.68 \pm 0.93$ & $2.54 \pm 0.73$ \\
\hline Cd Ranges & $(0.03-0.05)$ & $(0.03-0.04)$ & $(0.02-0.03)$ & $(0.01-0.04)$ & $(0.01-0.04)$ \\
\hline Mean \pm S.D & $0.04 \pm 0.01$ & $0.03 \pm 0.01$ & $0.03 \pm 0.01$ & $0.02 \pm 0.01$ & $0.02 \pm 0.01$ \\
\hline Ni Ranges & $(0.13-2.61)$ & $(0.10-0.89)$ & $(0.07-0.70)$ & $(0.03-0.74)$ & $(0.07-0.68)$ \\
\hline Mean \pm S.D & $0.98 \pm 1.05$ & $0.42 \pm 0.35$ & $0.34 \pm 0.30$ & $0.31 \pm 0.35$ & $0.29 \pm 0.28$ \\
\hline Pb Ranges & $(0.45-2.03)$ & $(0.36-0.83)$ & $(0.32-0.62)$ & $(0.32-0.76)$ & $(0.28-0.76)$ \\
\hline Mean \pm S.D & $0.87 \pm 0.67$ & $0.55 \pm 0.22$ & $0.45 \pm 0.12$ & $0.49 \pm 0.19$ & $0.38 \pm 0.23$ \\
\hline Mn Ranges & $(3.81-6.40)$ & $(1.67-4.31)$ & $(1.81-4.17)$ & $(1.39-3.87)$ & $(1.20-3.19)$ \\
\hline Mean \pm S.D & $5.65 \pm 1.06$ & $3.11 \pm 1.01$ & $2.99 \pm 1.05$ & $2.41 \pm 0.94$ & $2.15 \pm 0.98$ \\
\hline
\end{tabular}

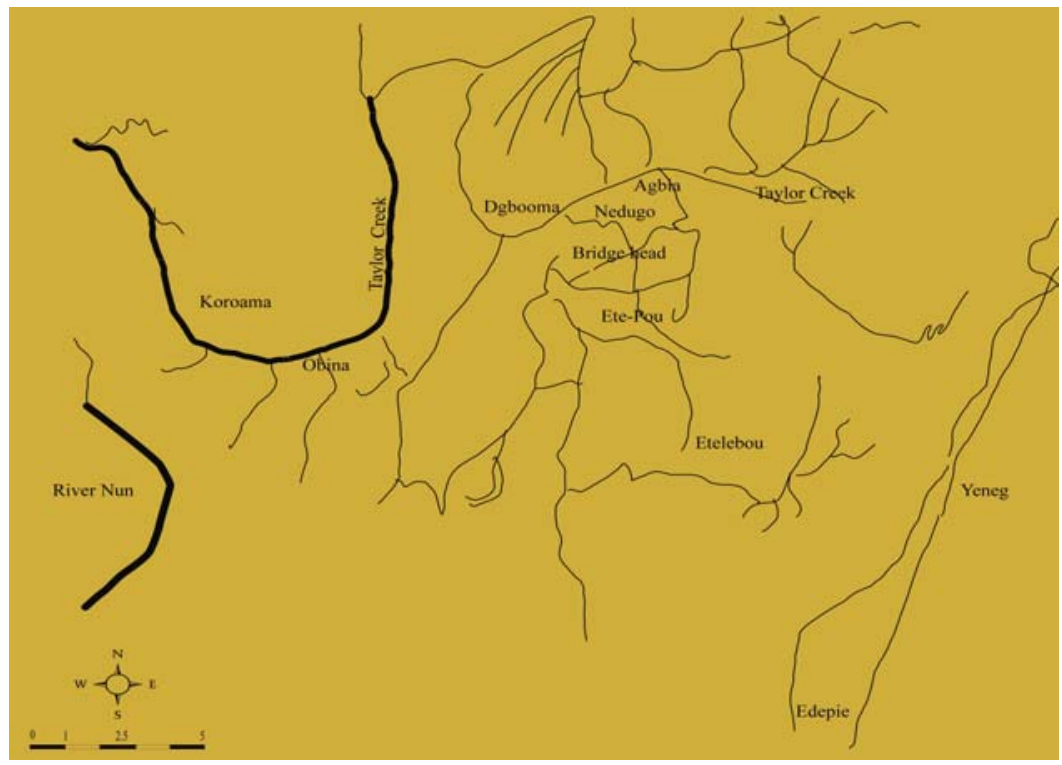

Fig. 1: Study location and sampling site map

\section{DISCUSSION AND CONCLUSION}

The Etelebou flow station (station 1) showed the highest concentration of all the heavy metals. Rural and agricultural runoff as well as continuous discharge of oily wastewaters from the flow station is suspected to be responsible for the observed metal levels. Varying concentrations of trace metals such as $\mathrm{V}, \mathrm{Ni}, \mathrm{Fe}, \mathrm{Al}, \mathrm{Cu}$, $\mathrm{Pb}, \mathrm{Cd}, \mathrm{Hg}$ and $\mathrm{Ba}$ have been implicated in crude oils and wastes generated from production operations (Nwadinigwe and Nwaorgu, 1999; DPR, 1991). The mean levels of Zn varied between 2.54 and $3.59 \mu \mathrm{g} / \mathrm{g}$ in the Creek. The mean levels were by far higher than the reported levels of $0.02 \mu \mathrm{g} / \mathrm{g}$ from rivers of South Carolina (Koli, et al, 1978) but lower than those of Kaduna River, Nigeria (6.60 g/g) (Nwaedozie, 1998). Alabaster and Lloyd (1980) posited that zinc has low toxicity to man, but relatively high toxicity to fish. The appreciable levels recorded in the catfish in this study would therefore be a serious cause for concern. The mean levels of Cd (0.02-0.04 $\mu \mathrm{g} / \mathrm{g})$ recorded in this study were low. However, the values were higher than the reported values of $<0.01 \mu \mathrm{g} / \mathrm{g}$ in rivers of South Carolina (Koli, et al., 1978). The highest Cd level recorded at the flow station is an indication of anthropogenic input. Cadmium has been known to have contributed to pulmonary disease, reduced glucose tolerance, severe kidney and liver damage and death in human beings (Voogt, et al,1980). Remarkably high level of nickel (Ni) metal was recorded in all the sampled stations. The results further revealed that $\mathrm{Ni}$ was bio-accumulated more in the catfish from the flow station environment $(0.98 \mu \mathrm{g} / \mathrm{g})$. The levels reported in this study are an indication of pollution particularly, when this metal had been classified as very toxic to 
Survey of heavy metals in the catfish Synodontis clarias

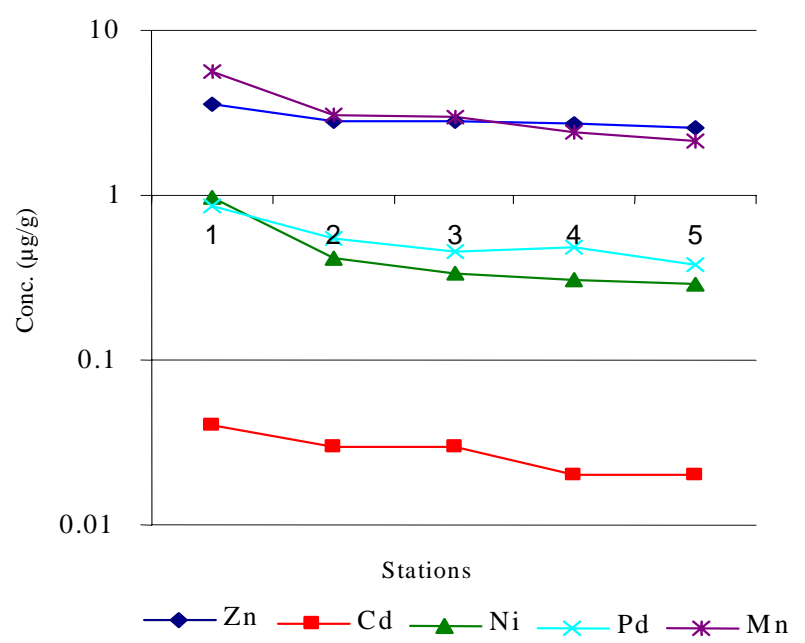

Fig. 2: Heavy metal concentrations (mg/g) Vs stations

aquatic life and relatively accessible (Forstner and Wittman, 1983). The mean levels of $\mathrm{Pb}$ varied between 0.38 and $0.87 \mu \mathrm{g} / \mathrm{g}$ in the catfish samples.The mean values of $0.87 \mathrm{mg} / \mathrm{g}$ recorded at the flow station environment was higher than the reported mean value of $0.56 \mathrm{mg} / \mathrm{g}$ from Kaduna River, Nigeria (Nwaedozie, 1998). Lead is known as a deadly and cumulative poison even when consumed in small quantities and is capable of deadening nerve receptors in man (Bodansky and Latner, 1987). The mean levels of Mn ranges from 2.15 to 5.64 ugg $^{-1}$ in the catfish samples. Manganese levels were higher than the other metals investigated in this study (Fig. 2). Similar trend in metal levels was observed from sediments in the study area (Agbozu and Ekweozor, 2004). Heavy metals are known to accumulate in the sediments, which act as sink for these pollutants. It therefore follows that catfishes, known as bottom feeders, would record elevated levels in the study area. The high levels of metals in the catfish gives cause for concern when viewed in perspective to Community Health issues, as the communities depend directly on catfish as a major protein source. Also, there is likely imbalance in the health of the community structure of the ecosystem. The appreciable levels of $\mathrm{Zn}, \mathrm{Cd}, \mathrm{Ni}, \mathrm{Pb}$ and $\mathrm{Mn}$ observed in this study would have detrimental effect on the health of the rural community (the ultimate consumers in the food chain) in the study area. The levels observed may affect the "health" of the aquatic ecosystem. The results of the study also revealed that the Etelebou flow station is a major point source of pollutants to the Creek. It is therefore recommended that more stringent waste management/control measures should be adopted to reduce the amount/levels of pollutants discharged into the Creek by oil industry activities. As a result of the probable impact of these pollutants on community health, the State Environmental Protection Authority and/or relevant authorities should institute quarterly monitoring programmes on the levels of these pollutants in the water body and other environmental segments that may be affected within the area.

\section{REFERENCES}

Ackefors, H., Lofroth, G., Rosen, C.G., (1970). A survey of the mercury pollution problems in Sweden with reference to fish. Oceanogr. Mar. Biol., 203-224.

Agada, E.G.O. (1994). Heavy metals concentration in selected fish fauna of Warri River and its tributaries Ph.D Thesis of University of Benin, Benin city, Nigeria.

Agbozu, I.E., (1999). Impact of economic activities on the environment of Niger Delta. Envisafe Global Environmental and safety memoirs. GESM: 99-100.

Agbozu, I.E., Ekweozor, I.K.E., (2001). Heavy metals in a nontidal freshwater swamp in the Niger Delta areas of Nigeria. African J. Sci., 2, 175-182.

Agbozu, I.E., Ekweozor, I.K.E., (2004). Heavy metals in sediments from lower Taylor Creek in the Niger Delta area of Nigeria. African J. Sci., 5 (1), 1043-1049.

Alabaster, J.S., Lloyd, R., (1980). Water quality criteria for fish, $2^{\text {nd. }}$ Ed., London, Butterworths.

Atuma, S.O., Egborge, A.B.M., (1986). Insecticides and metals in Nigeria surface waters-Warri River. Int. J. Environ. Stud., 27,139-142.

Bodansky, O., Latener, A. L., (1987). Advances in Clinical Chemistry. Volume 20 Academic Press. New York. 288.

Cantillo, A., Calder, J., (1990). Reference materials for marine science. Fresenius J. Anal. Chem., 338: 380-382.

Department of petroleum resources, (2002). Environmental Guidelines and Standard for the Petroleum Industry in Nigeria. DPR, Lagos. 
Department of water affairs \& forestry, (1996). Water Quality Guidelines, Aquatic Ecosystem use. Volume 7, $1^{\text {st. }}$ Ed. DWAF, Pretoria.

Ezemonye, L.I.N., Egborge, A.B.M., (1992). Heavy metal concentration in water, sediment and selected fish species in Warri River and its tributaries. Proc. $3^{\text {rd. National Seminar }}$ on Petroleum. Petroleum Training Institute. Effurun, Nigeria, 3, 91-112.

Forstner, U., Wittman, G.T.W., (1983). Metal pollution in the Aquatic Environment, $2^{\text {nd. }}$ Ed., Verlag Publishers. New York. 18-9.

Ibok, U.J., Udosen, E.D., Udoidiong, O.M., (1989). Heavy metals in fishes from some streams in Ikot Ekpene Area of Nigeria. Nig. J. Tech Res., 1, 61-68.

Kakulu, S.E., Osibanjo, O., ajayi. S.O., (1987). Trace metal content of fish and shellfishes of the Niger Delta Area of Nigeria. Environ. Int., 13, 247-251.

Koli, A.K., Canty, W.T., Felix, K.I., Reed, R.J., Whitmore, R., (1978). Trace metals in some fish species of South Carolina. Bull Env. Cont. Toxic., 20 (3), 328-331.
Merian, E., (1991). Metals and their compounds in the Environment. Occurrence, Analysis and Biological Relevance. UCH. Weinhein-New York-Basel-Cambridge.

Nwadinigwe, C.A. and Nwaorgu, O.N., (1999). Metal contaminants in some Nigerian well-head crudes: Comparative analysis. J. Chem. Soc. Nigeria. 24, 118-121.

Nwaedozie, J.M., (1998). The determination of heavy metal pollution in some fish samples from River Kaduna. J. Chem. Soc. Nigeria, 23, 21-23.

Tam, N.F.Y., Wong, Y.S., (1995). Spatial and temporal variations of heavy metal contamination in sediments of a mangrove swamp in Hong Kong-Marine pollution Bulletin, 11, 254-261.

Voogt dept van, H.B., Feemstra, J.P., Copius peeretom, J.W., (1985) Exposure and health effects of cadmium. Toxic. Environ. Chem. Rev., (3), 89-109.

Window, C.H., Cutshall, N., (1976). Atomic absorption spectrophotometry. In strategies for Marine Pollution monitoring. Goldberg, E.D. (Ed). Wiley Intr. Science Publ. London. 161-184.

\section{AUTHOR (S) BIOSKETCHES}

Agbozu, I.E., Ph.D., lecturer in the Department of Pure and Applied Chemistry, Niger Delta University, Wilberforce Island, Yenagoa, Nigeria. Email: iwekumo@yahoo.co.uk

Ekweozor, I.K.E., Ph.D., associate professor in the Department of Applied and Environmental Biology, Rivers University of Science and Technology, Port Harcourt, Nigeria.

Email: ekweozor@yahoo.com

Opuene, K., Ph.D., postdoctoral assignment in the Department of Pure and Industrial Chemistry, Faculty of Physical Sciences, University of Nigeria, Nsukka. Nigeria. Email: opuenekings@yahoo.com

This article should be referenced as follows:

Agbozu, I.E., Ekweozor, I.K.E., Opuene, K., (2007). Survey of heavy metals in the catfish Synodontis clarias.

Int. J. Environ. Sci. Tech., 4 (1), 93-97. 